\title{
Various Types of Polyurethanes in the process of Chemical Recycling
}

\author{
Silke Beckmann, Michael Herzog*
}

\section{Abstract}

Increasing raw material costs and more stringent regulations have led to more pressure to develop customer-oriented recycling processes for polyurethanes. Furthermore, waste disposal runs into increasing costs for the producers while old methods of disposal are prohibited legally, both in the US and Europe. One way to solve this problem is to develop a well-suited process and plant for a customer specialised procedure to re-use the waste material obtained for each type of polyurethane product. Based on the previously described simultaneous glycolysis and aminolysis of polyurethanes in this paper, we will report on first results on larger scale recycling of some polyurethane products. While we were initially focused on the use of the recycling products (recycling polyols) to produce new types of polyurethanes, e. g. from cold moulded foams sealants or coatings, the philosophy had to be changed to use the recycling polyols as much as possible to produce the same materials as originally. This route was consequently developed further to other polyurethane products and the incorporation of the recycling polyols into original premixes to be reacted with isocyanates.

\section{Zusammenfassung}

Steigende Materialkosten und verschärfte regulatorische Anforderungen sind Stressoren hin zu einem anwenderorientierten chemischen Recycling von Polyurethanen. Ferner ist die Abfallablagerung in den USA und Europa weitgehend nicht mehr möglich und die Entsorgung mit steigenden Kosten verbunden. Eine Möglichkeit, das Problem zu lösen, besteht darin, für jeden Polyurethan-Typ einen entsprechend angepassten Prozess einschließlich Anlagenauslegung für die Wiederverwendung des Abfallmaterials zu entwickeln. Aufbauend auf einer kombinierten Glykolyse und Aminolyse wird im vorliegenden Artikel über erste Ergebnisse einer Maßstabsvergrößerung an konkreten Polyurethan-Produkten berichtet. Die Zielrichtung zu Beginn war die Verwendung von Recycling-Produkten (Recycling-Polyolen) zur Herstellung von neuen Polyurethan-Typen, z.B. ausgehend von Kaltformweichschaumstoffen zu Dichtmassen oder Beschichtungen. Mit der nunmehr verfolgten Philosophie werden so viel wie möglich Recycling-Polyole in der Original-Rezeptur verwendet. Dieser Weg wurde konsequent für Polyurethanprodukte unter Einbeziehung von Recycling-Polyolen in ursprünglichen Mischungen zur Reaktion mit Isocyanaten weiterentwickelt.

\section{SHORT REVIEW OF THE PROCESS}

The combined glycolysis and aminolysis reaction make use of the re-esterification at the urethane group by the glycols present to liberate the polyetheralcohol originally employed and an amidation reaction with cleavage of the urethane group to produce a trisubstituted urea and the originally present alcohol (Stoychev et al. 2010). The polyureas present remain mainly unchanged, only on extended addition or reaction times the cleavage by the glycolic hydroxyl groups to form primary aromatic amines occurs as an undesirable side reaction
(Stoychev et al. 2011).

Depending on the type of polyurethane to be treated, the glycol is either only a monomer or an oligomer or, as in most cases, is a mixture of several glycols so as to produce optimum product quality and ease the dissolution of the solid particles. As has been shown previously (Langenstraßen et al. 2001), the type of glycol determines the rate of reaction to some extent but more the viscosity of the recycling polyol and the final properties of the new polyurethane produced from it. An additional feature is the particle size of the grafted polymers from grafted polyols used which may be established by proper choice of the glycol mixture (see further chapters).

The recycling polyols may be produced by the batch, or continuously (Schmidt et al. 2001). The batch process makes use of jacketed stainless steel reactors with a volume up to 6 metric tonnes with specially designed periphery equipment and a specially designed dosage unit so as to receive a continuous flow of solid particles with optimum rate into the reactor. The reactor outlet is connected to a filtering unit to filter off any insoluble material and additionally 
to be able to apply a certain reduced pressure to degas the recycling polyol if necessary. There is no need for further treatment of the recycling polyol, moreover, it is used as produced (Behrendt \& Pohl 1999, 2004b, 2004a). In the continuous process, a twin screw reactor is typically used where the shafts of the screws and the mantle are both heated to the reaction temperature by a heat transfer medium, usually thermal oil. The feed is made by a screw to densify the material and by dosage pumps and the outlet is again connected to a filtering unit and a suction pump.

\section{MATERIALS AND METHODS}

\subsection{MATERIALS}

Diethylene glycol (DEG), dipropylene glycol (DPG), polyethylene glycols (PEG) of molecular weight 200 and 400 , and polypropylene glycol (PPG) of molecular weight 400 were obtained by Fluka AG and used without further purification, polypropylene glycol 2000 was a gift of Elastogran AG, Germany, dinbutyl amine (DBA) was purchased from Merck KGaA, Darmstadt, Germany, and used without further treatment. Catalysts used were Dabco 33 LV as a gift from Air Products and Polycat NP 40 from Performance chemicals $\mathrm{GmbH}$. Stabilizers of various types were generously given by Th. Goldschmidt AG.

The various types of polyurethanes were samples from producers of Germany, Japan, Mexiko, Poland, the USA, Bulgaria, or Portugal.

\subsection{METHODS}

First experiments were generally performed in small-scale lab glass ware: a $750 \mathrm{ml}$ four necked glass flask with stirrer, thermometer, reflux and solids inlet. The liquids were placed into the reactor, heated to $180^{\circ} \mathrm{C}$, and the solids introduced with stirring as fast as possible while the temperature was slowly increased to the final reaction temperature. At this, the mixture was kept after completion of the addition another 30 to 60 minutes. The reaction mixture was allowed to cool down, filtered, and subjected to analysis.
The next step was the first scale up to a $1.75 \mathrm{~kg}$ batch in a 2.5 I glass reactor. The apparatus was as before and so is the process. For filtering, in this case was used a pressurized filter with a 120 mesh screen where the pressure was obtained from compressed nitrogen and applied with up to $25 \mathrm{kp} / \mathrm{cm}^{2}$.

The third step in up-scaling was the use of a 100 I stainless steel reactor heated by thermal oil and stirred by a blade stirrer at $60 \mathrm{rpm}$. The process was the same as before, for filtering a suction filter was directly connected to the bottom outlet and used together with a membrane vacuum pump. The reactor was equipped with a three stage heat exchanger consisting of demister, first heat exchanger adjusted to a predetermined temperature and a second heat exchanger to collect any low boiling liquids.

\section{RESULTS}

\subsection{RECYCLING POLYOLS FROM AUTOMOTIVE PRODUCTS}

From automotive wastes, mainly seat cushions, i.e. cold moulded foams, ceiling elements, i.e. rigid reinforced foams, and wheel mould flashes, i.e. microcellular elastomers or flexible integral foams, were reacted to form recycling polyols.

Cold moulded foams were delivered by two main German manufacturers as complete cushions that did not meet standards. These were cut to flakes of about $8 \mathrm{~cm}$ size by a shredder. The flakes were introduced into the respective reactor without further treatment or separation.

The seats were used in an amount between 50 and $75 \%$ by weight to produce recycling polyols with viscosities ranging from 2,000 to $30,000 \mathrm{mPas}$ $\left(25^{\circ} \mathrm{C}\right)$ and hydroxyl numbers of 350 to about $270 \mathrm{mg} \mathrm{KOH} / \mathrm{g}$. The aim was to add the recycling polyols to premixes to result in elastic products again. Mainly, the recycling polyols were used as additives with 15 to $25 \%$ by weight in premixes to produce flexible cold moulded foams. Additionally, they were used to produce new types of material, e. g. sealants or steel tank coatings (Evtimova et al. 2004) or composites with wood fiberes (Belke et al. 2003). Table 1 depicts some examples of recycling polyols as derived from cold molded foams.

By the process described from cold moulded flexible foams, recycling polyols can be prepared with a viscosity in the range between 3,500 and $27,000 \mathrm{mPas}\left(25^{\circ} \mathrm{C}\right)$ with waste loads of the mixture between 60 and $75 \%$ by weight. In the range of about $65 \%$ by weight of solids the viscosity is established in the range between 4,000 and $11,000 \mathrm{mPas}$ with hydrox$\mathrm{yl}$ numbers of about $300 \mathrm{mg} \mathrm{KOH} / \mathrm{g}$. These recycling polyols maybe used as an additive to commercial premixes or added as an additional feed to the foaming mixture up to $30 \%$ by weight. The resultant foams increase somewhat in hardness but do not suffer a loss in low temperature performance or comfort.

Integral foams processed were polyether based systems used to produce steering wheel shells of which the mould flashes were shreddered to pieces of about $5 \mathrm{~cm}$ thickness. The flakes were subjected to several investigation of the system in which the amount of solids, the amine content, and the reaction time were systematically investigated.

As in the case of the cold moulded Foams, the optimum amount of polyurethane solids is again in the range of 60 to $65 \%$ by weight where the viscosity is of a magnitude allowing the recycling polyol to be added to a premix or processed as one of the components of the foaming mixture. The addition of the secondary amine leads to a rather high amine number in the lab scale experiments. This does not significantly affect the processing times, but may in some cases lead to a decrease in the amount of catalyst. The investigation of several amine concentrations is presented in table 3. As shown in table 3 , the amine concentration does not significantly affect the amine number. It only results in a further increase at concentrations beyond $4 \%$ by weight. This limit is different for any type of polyurethane and depends on the concentration of urethane groups present in the polymer. Most effect is contributed by the reaction time as shown in table 4 . 
Tab. 1: Recycling polyols from flexible cold molded foams

\begin{tabular}{|c|c|c|c|c|c|}
\hline Item/No. & 191 & 192 & 194 & 198 & 130 \\
\hline PUR (\% by weight) & 65,0 & 70,0 & 63,0 & 62,5 & 75,0 \\
\hline DPG (\% by weight) & 30,0 & 25,0 & 32,0 & 32,5 & 23,3 \\
\hline DBA (\% by weight) & 5,0 & 5,0 & 5,0 & 5,0 & 1,7 \\
\hline Reaction temperature ( $\left.{ }^{\circ} \mathrm{C}\right)$ & 210 & 210 & 210 & 210 & 200 \\
\hline Reaction time (min) & 55 & 60 & 55 & 45 & 115 \\
\hline Appearance & turbid & viscous & clear & clear & inhomogeneous \\
\hline OH-No. (mg KOH/g) & 299 & 251 & 310 & 303 & 213 \\
\hline Amine No. (mg KOH/g) & 48 & 15 & 17 & 18 & 21 \\
\hline Viscosity $\left(25^{\circ} \mathrm{C}\right)(\mathrm{mPas})$ & 11,500 & 17,800 & 4,100 & 3,680 & 27,000 \\
\hline
\end{tabular}

Tab. 2: Recycling polyols made with varying the amount of polyurethanes

\begin{tabular}{|c|c|c|c|c|c|}
\hline No. & $\begin{array}{c}\text { PUR } \\
\text { (\% by weight) }\end{array}$ & $\begin{array}{c}\text { Reaction time } \\
(\mathrm{min})\end{array}$ & $\begin{array}{c}\text { OH No. } \\
\mathrm{mg} \mathrm{KOH} / \mathrm{g}\end{array}$ & $\begin{array}{c}\text { Amine No. } \\
\mathrm{mg} \mathrm{KOH} / \mathrm{g}\end{array}$ & $\begin{array}{c}\left.\text { Viskosity (25 }{ }^{\circ} \mathrm{C}\right) \\
(\mathrm{mPas})\end{array}$ \\
\hline 149 & 70,0 & 190 & 225 & 29 & 15,030 \\
\hline 158 & 65,0 & 110 & 266 & 27 & 6,600 \\
\hline 146 & 63,0 & 90 & 310 & 28 & 10,800 \\
\hline 150 & 60,0 & 100 & 269 & 22 & 5,130 \\
\hline 143 & 55,0 & 105 & 351 & 23 & 4,850 \\
\hline 151 & 50,0 & 80 & 336 & 20 & 2,020 \\
\hline 152 & 40,0 & 65 & 413 & 16 & 1,230 \\
\hline
\end{tabular}

Tab. 3: Systematic variation of the amount of di-n-butyl amine in batches with $60 \%$ by weight polyurethane solids load

\begin{tabular}{|c|c|c|c|c|c|}
\hline No. & $\begin{array}{c}\text { DBA } \\
\text { (\% by weight) }\end{array}$ & $\begin{array}{c}\text { Reaction time } \\
(\mathrm{min})\end{array}$ & $\begin{array}{c}\text { Hydroxyl No. } \\
(\mathrm{mg} \mathrm{KOH} / \mathrm{g})\end{array}$ & $\begin{array}{c}\text { Amine No. } \\
(\mathrm{mg} \mathrm{KOH} / \mathrm{g})\end{array}$ & $\begin{array}{c}\text { Viskosity }\left(25^{\circ} \mathrm{C}\right) \\
(\mathrm{mPas})\end{array}$ \\
\hline 153 & 1,0 & 95 & 336 & 24 & 6880 \\
\hline 154 & 2,0 & 95 & 335 & 25 & 7700 \\
\hline 155 & 3,0 & 95 & 336 & 28 & 5640 \\
\hline 156 & 4,0 & 95 & 338 & 31 & 5280 \\
\hline 157 & 5,0 & 95 & 335 & 36 & 5340 \\
\hline
\end{tabular}

Tab. 4: Systematic variation of the reaction time in batches with constant polyurethane solids load at $200^{\circ} \mathrm{C}$

\begin{tabular}{|c|c|c|c|c|c|}
\hline No. & $\begin{array}{c}\text { DBA } \\
\text { (\% by weight })\end{array}$ & $\begin{array}{c}\text { Reaction time } \\
(\mathrm{min})\end{array}$ & $\begin{array}{c}\text { Hydroxyl No. } \\
(\mathrm{mg} \mathrm{KOH} / \mathrm{g})\end{array}$ & $\begin{array}{c}\text { Amine No. } \\
(\mathrm{mg} \mathrm{KOH} / \mathrm{g})\end{array}$ & $\begin{array}{c}\text { Viscosity }\left(25^{\circ} \mathrm{C}\right) \\
(\mathrm{mPas})\end{array}$ \\
\hline 159 & 63,2 & 50 & 246 & 17 & 9650 \\
\hline 160 & 63,2 & 65 & 241 & 20 & 8360 \\
\hline 161 & 63,2 & 80 & 243 & 25 & 5900 \\
\hline 162 & 63,2 & 95 & 244 & 26 & 6600 \\
\hline 163 & 63,2 & 110 & 254 & 24 & 5500 \\
\hline 164 & 63,2 & 125 & 230 & 20 & 9610 \\
\hline
\end{tabular}


The reaction time of the mixture after completing the addition of the polyurethane foam flakes increases corresponding to the increasing the reaction time, reaching a limit after about 90 minutes. Shorter reaction times (addition and post reaction) such as 50 minutes could not be established under lab conditions with suitable amounts of reactands (i. e. a batch size of $500 \mathrm{~g}$ ). In continuous production, this number maybe decreased further by establishing reaction times of 20 minutes. Shorter reaction times will not be suitable even at temperatures exceeding $250^{\circ} \mathrm{C}$ as demonstrated and proven by experiments conducted with a continuous and a semi-continuous reactor, as the reaction is not complete. The experiments performed to this point with up to a batch size of $90 \mathrm{~kg}$ demonstrate the integral foams to be processable to recycling polyols with suitable properties. The somewhat higher viscosity as compared with the polyols received from the cold moulded foams may be attributed to the different formulation and the load of solids (pigments and fillers). The wastes employed were glass fibre reinforced high density foams as used in car ceilings having an estimated density of $65 \mathrm{~g} / \mathrm{dm}^{3}$. The glass fibres were of 20 to $48 \mathrm{~mm}$ length before the experiment and decreased to 12 to 27 $\mathrm{mm}$ length after. The fibres were separated by simple filtration via a Buchner funnel. The unknown formulation of the rigid foam led to lower degrees of solids content in the experiments as shown in table 5 .

The rigid foams were transformed with $40 \%$ by weight into polyols of hydroxyl numbers of about $400 \mathrm{mg} \mathrm{KOH} / \mathrm{g}$ and viscosities in the range of $8,000 \mathrm{mPas}$ $\left(25^{\circ} \mathrm{C}\right)$ when any solids were filtered off. The solids were glass long fibres or solids consisting of other polymers (mainly polyolefins) which had to be separated before they could further processed to give rigid foams without reinforcements under lab scale conditions. The increases of the reaction temperature. In this case lead to a tremendous increase in viscosity. The source of this increase is not yet clear but may be attributed to finely dispersed solids and fillers of the original foam to produce structural viscous liquids.

\subsection{FLEXIBLE SLABSTOCK FOAMS}

Flexible slabstock foams are produced from polyether systems, polyester systems, and mainly based on grafted polyether systems. Each of these types needs a detailed investigation and a specially developed solvolysis mixture and processing technology. Furthermore, the final product properties need to be carefully determined by the customer according to his technology before process development to adjust both viscosity and hydroxyl content (Behrendt \& Naber 2009).

Flexible slabstock based on polyester systems was solvolysed using a typical mixture to give viscous recycling polyols of light amber colour. They were produced by batch technology in small and $6 \mathrm{~kg}$ batches. The results are depicted in table 6.

With this type of slabstock foam, the viscosities of the recycling polyols are generally high as are the original polyester polyols. They may be processed into the premixes at higher temperature to result in flexible foams again. The limit of application into a typical premix was determined to be $15 \%$ by weight at present. Further experiments were performed to reduce the viscosity and to be able to use more than the limiting $15 \%$ by weight in a premix. Some results of such experiments are presented in table 7.

The addition of only a few percent into the reaction mixture reduces clearly the viscosity to values suitable for use in the production. The recycling polyols are clear, amber liquids without any solid side products. The incorporation of these recycling polyols into slabstock foam formulations (free rise under lab conditions) led to a decrease in hardness and a higher degree of softness with lower ball rebound. This may be attributed to the interference of the short chain triols with phase build up during foaming and polymer formation.

The materials used in further experiments were flexible slabstock foam residues from the outer part of the block with densified skins having a determined density of $34.5 \mathrm{~g} / \mathrm{dm}^{3}$ of the foam part. Some results are shown in table 8.

The results with polyether flexible slabstock foams are similar to those obtained with cold moulded foams, i. e., in a range of solids, load to the reaction mixture of a bout $60 \%$ by weight recycling polyols with suitable viscosities can be attained. The increase in the solid content as shown with batch 116 leads to a sharp increase in viscosity while the hydroxyl number accordingly decreases. In application of such recycling polyols, an optimum for viscosity and hydroxyl content has to be found to have both a maximum amount of recycling polyol added to the foaming mixture and optimum processing conditions. Flexible slabstock foams based on grafted polyether polyols are the main product in this field today, but present the greatest issue as well. The problem is centered on the solids content which maybe either separated and disposed of or dispersed in the recycling polyol as fine particles. As the reaction temperature typically exceeds the melting temperature of the grafted polymer chains, a special technology had to be developed to produce stable dispersions. A further limitation may arise from the polyureas present in the recycling polyol resulting in the combination of both viscosity problems through the buildup of tixotropy or of a high portion of non-Newtonian viscosity (structural viscosity). When developing a technology to separate the grafts, the solvolysis mixture needs to have a well-adjusted surface tension which is established by the use of a carefully selected mixture of short chain glycols. Some examples are presented in table 9, using batches that were produced on $1 \mathrm{~kg}$ basis to receive the grafts as filterable solids.

The technology and solvolysis mixture used in these experiments resulted in homogeneous recycling polyols of clear, light amber appearance with a viscosity as low as $1,500 \mathrm{mPas}\left(25^{\circ} \mathrm{C}\right)$ due to the low solids content. A precipitate formed of solid needles of about 4 to $6 \mathrm{~mm}$ length and 0.5 to $1.5 \mathrm{~mm}$ thickness or particles of about $0.2 \mathrm{~mm}$ diameter which turned out to be the grafted polymers. The needle-like and the particulate material could be easily filtered off both at room temperature and at $75^{\circ} \mathrm{C}$ while the latter temper- 
Tab. 5: Recycling polyols from reinforced rigid foams

\begin{tabular}{|c|c|c|c|}
\hline Item/No. & 166 & 168 & 169 \\
\hline Foam (\% by weight) & 40,1 & 40,1 & 40,1 \\
\hline DPG (\% by weight) & 29,2 & 29,2 & 29,2 \\
\hline DEG (\% by weight) & 35,2 & 29,2 & 29,2 \\
\hline DBA (\% by weight) & 1,5 & 1,5 & 1,5 \\
\hline Temperature $\left({ }^{\circ} \mathrm{C}\right)$ & 200 & 220 & 230 \\
\hline Time $(\mathrm{min})$ & 40 & 45 & 40 \\
\hline OH-No. $(\mathrm{mg} \mathrm{KOH} / \mathrm{g})$ & 381 & 387 & 473 \\
\hline Amine No. $(\mathrm{mg} \mathrm{KOH} / \mathrm{g})$ & 36 & 32 & 38 \\
\hline Viscosity $\left(25^{\circ} \mathrm{C}\right)(\mathrm{mPas})$ & 7,750 & 28,500 & $>50,000$ \\
\hline
\end{tabular}

Tab. 6: Recycling polyols from polyester slabstock foam

\begin{tabular}{|c|c|c|c|c|c|}
\hline Item / No. & 110 & 111 & 112 & 115 & 113 \\
\hline Foam (\% by weight) & 53,8 & 57,7 & 62,3 & 65,0 & 67,5 \\
\hline DPG (\% by weight) & 44,8 & 40,9 & 36,3 & 33,5 & 31,0 \\
\hline DBA (\% by weight) & 1,4 & 1,3 & 1,4 & 1,5 & 1,5 \\
\hline Temperature ( $\left.{ }^{\circ} \mathrm{C}\right) /$ time (min) & $180 / 60$ & $220 / 60$ & $220 / 80$ & $220 / 85$ & $220 / 60$ \\
\hline Hydroxyl No. (mg KOH/g) & 303 & 331 & 292 & 290 & 275 \\
\hline Amine No. (mg KOH/g) & 45 & 46 & 46 & 42 & 43 \\
\hline Viscosity $\left(25^{\circ} \mathrm{C}\right.$ ) (mPas) & 10,530 & 8,690 & 19,370 & 16,880 & 32,300 \\
\hline
\end{tabular}

Tab. 7: Modified recycling polyols from polyester slabstock foam

\begin{tabular}{|c|c|c|c|c|c|}
\hline Item / No. & 122 & 124 & 130 & 131 & 132 \\
\hline Foam (\% by weight) & 65,0 & 71,0 & 75,0 & 57,7 & 57,7 \\
\hline DPG (\% by weight) & 33,5 & 27,4 & 23,3 & 38,9 & 36,8 \\
\hline Short chain triol(\% by weight) & 0 & 0 & 0 & 2,0 & 4,1 \\
\hline DBA (\% by weight) & 1,5 & 1,6 & 1,7 & 1,3 & 1,4 \\
\hline Temperature ( ${ }^{\circ} \mathrm{C}$ )/time (min) & $200 / 80$ & $220 / 80$ & $220 / 80$ & $220 / 80$ & $220 / 80$ \\
\hline Hydroxyl No. (mg KOH/g) & 304 & 278 & 213 & 348 & 346 \\
\hline Amine No. (mg KOH/g) & 42 & 45 & 41 & 42 & 42 \\
\hline Viscosity $\left(25^{\circ} \mathrm{C}\right.$ ) (mPas) & 12,500 & 32,400 & 27,000 & 6,200 & 7,600 \\
\hline
\end{tabular}

Tab. 8: Recycling polyols from polyether slabstock foam

\begin{tabular}{|c|c|c|c|c|}
\hline Item / No. & 116 & 117 & 119 & 121 \\
\hline Foam (\% by weight) & 70,0 & 57,7 & 57,7 & 57,6 \\
\hline DPG (\% by weight) & 28,3 & 40,9 & 40,9 & 40,9 \\
\hline DBA (\% by weight) & 1,6 & 1,4 & 1,4 & 1,5 \\
\hline Temperature $\left({ }^{\circ} \mathrm{C}\right)$ /time (min) & $200 / 80$ & $220 / 80$ & $220 / 60$ & $220 / 95$ \\
\hline Hydroxyl No. (mg KOH/g) & 241 & 355 & 361 & 356 \\
\hline Amine No. (mg KOH/g) & 41 & 41 & 41 & 41 \\
\hline Viscosity $\left(25^{\circ} \mathrm{C}\right)(\mathrm{mPas})$ & 57,750 & 4,200 & 3,880 & 3,780 \\
\hline Appearance & amber, with particles & light amber, clear & yellow, clear & yellow, clear \\
\hline
\end{tabular}


ature was preferred because of the much lower viscosity of the recycling polyol. The filtered recycling polyol was used as an additive up to $25 \%$ by weight in a typical formulation to produce polyether slabstock foams again.

When aiming at dispersed solids in the recycling polyols the technology and the solvolysis mixture had to be changed: the rate of the stirrer was increased to about $1200 \mathrm{rpm}$ and the solvolysis mixture adjusted to a higher surface tension by the choice of the glycols. Some results are presented in table 10.

As shown in the table, by the process and technology developed recycling polyols with homogeneously dispersed non-settling solids and rather low viscosities could be obtained when applying a solids load between 55 and $70 \%$ by weight. The viscosities as measured by oscillation or rotation mode (Haake Rheostress ${ }^{\circledR} 300$ ) possess a difference of roughly 800 $\mathrm{mPas}$ at $25^{\circ} \mathrm{C}$ which shows a high degree of structural viscosity originating from the combined action of the grafted polymers and the oligoureas present in the mixture.

The polyols thus obtained were introduced into a simple flexible foam mixture in the free rise mode (see formulation S1065 for details). In this formulation, part of the polyether polyol Lupranol $^{\circledR} 2085$ was substituted by the recycling polyols. The composition and some properties of the foams obtained are shown in table 11.
Tab. 9: Solvolysis of grafted polyether based flexible slabstock foam aimed at filterable solids (temperature always $220^{\circ} \mathrm{C}$, reaction time 30 minutes)

\begin{tabular}{|c|c|c|c|}
\hline \begin{tabular}{c} 
Item/No. \\
\hline $\begin{array}{c}\text { PUR foam (\% by } \\
\text { weight) }\end{array}$
\end{tabular}$\quad 40,0$ & 142 & 145 \\
\hline $\begin{array}{c}\text { DPG (\% by } \\
\text { weight) }\end{array}$ & 43,1 & 40,0 & 40,0 \\
\hline $\begin{array}{c}\text { Short chain triol } \\
\text { (\% by weight) }\end{array}$ & 14,4 & 48,1 & 51,7 \\
\hline $\begin{array}{c}\text { DBA (\% by } \\
\text { weight) }\end{array}$ & 2,5 & 9,4 & 5,8 \\
\hline $\begin{array}{c}\text { Appearance } \\
\text { Hydroxyl No. }\end{array}$ & $\begin{array}{c}\text { Grey liquid with } \\
\text { needle-like solids }\end{array}$ & $\begin{array}{c}\text { Yellow liquid } \\
\text { with solid phase }\end{array}$ & $\begin{array}{c}\text { Yellow liquid with } \\
\text { solid particles }\end{array}$ \\
\hline $\begin{array}{c}\text { Amine No. (mg } \\
\text { KOH/g) }\end{array}$ & 445 & 437 & 450 \\
\hline $\begin{array}{c}\text { Viscosity (25 } \\
\text { (mPas) }\end{array}$ & 4,480 & 45 & 43 \\
\hline
\end{tabular}

Tab. 10: Solvolysis of grafted polyether based flexible slabstock foam aimed at homogenous polyols

\begin{tabular}{|c|c|c|c|c|c|}
\hline Item/No. & 139 & 105 & 195 & 196 & 197 \\
\hline Foam (\% by weight) & 50,0 & 50,0 & 60.0 & 55.0 & 65.0 \\
\hline DPG (\% by weight) & 36,0 & 37,6 & 29.75 & 34.85 & 26.4 \\
\hline DEG (\% by weight) & 12,0 & 9,4 & 5.25 & 6.15 & 4.6 \\
\hline DBA (\% by weight) & 2,0 & 3,0 & 5.0 & 4.0 & 4.0 \\
\hline Temperature $\left({ }^{\circ} \mathrm{C}\right)$ & 200 & 200 & 220 & 220 & 220 \\
\hline Time (min) & 80 & 60 & 70 & 85 & 60 \\
\hline $\mathrm{OH}-\mathrm{No} .(\mathrm{mg} \mathrm{KOH} / \mathrm{g})$ & 381 & 434 & 329 & 374 & 284 \\
\hline $\begin{array}{c}\text { Amine No. (mg } \\
\mathrm{KOH} / \mathrm{g})\end{array}$ & - & 62 & 24.4 & 24.5 & 44 \\
\hline $\begin{array}{l}\text { Viscosity oscillation } \\
\text { mode }\left(25^{\circ} \mathrm{C}\right) \text { (mPas) }\end{array}$ & - & - & 10,600 & 5020 & 7050 \\
\hline $\begin{array}{c}\text { Viscosity rotation } \\
\text { mode }\left(25^{\circ} \mathrm{C}\right)(\mathrm{mPas})\end{array}$ & - & 8,100 & 10,500 & 4300 & 6200 \\
\hline Appearance & slurry & $\begin{array}{c}\text { homoge- } \\
\text { neous, } \\
\text { amber }\end{array}$ & $\begin{array}{l}\text { homoge- } \\
\text { nuous, } \\
\text { dispersion }\end{array}$ & $\begin{array}{l}\text { homoge- } \\
\text { nuous, } \\
\text { dispersion }\end{array}$ & $\begin{array}{l}\text { homoge- } \\
\text { nuous, } \\
\text { dispersion }\end{array}$ \\
\hline
\end{tabular}


Tab. 11: Free rise foam composition and properties with the addition of the recycling polyols received from flexible slabstock foam based on grafted polyether alcohols (amounts given in \% by weight)

\begin{tabular}{|c|c|c|c|c|c|}
\hline Item/No. & S1040 & S1045 & S1046 & S1042 & S1043 \\
\hline Polyol 195 & 0 & 15.8 & 23.1 & & 15.8 \\
\hline Polyol 196 & 0 & 0 & 0 & 7.85 & 63.1 \\
\hline Lupranol $^{\circledR} 2095$ & 78.8 & 63.0 & 53.9 & 71.0 & 0.33 \\
\hline Polycat $^{\circledR}$ NP40 & 0.33 & 0.33 & 0.32 & 0.33 & 0.06 \\
\hline TEGOSTAB $^{\circledR} 8433$ & 0.06 & 0.06 & 0.06 & 0.06 & 1.05 \\
\hline Water & 1.05 & 1.06 & 1.02 & 1.05 & 19.7 \\
\hline Lupranat $^{\circledR} \mathrm{M} 20 A$ & 19.7 & 19.7 & 19.2 & 19.7 & 17 \\
\hline Start $(\mathrm{s})$ & 20 & 17 & 21 & 17 & 70 \\
\hline Index & 90 & 60 & 50 & 57 \\
\hline
\end{tabular}

Tab. 12: Recycling polyols obtained from polyester shoe soles

\begin{tabular}{|c|c|c|c|}
\hline Item/No. & 172 & 173 & 174 \\
\hline PUR (\% by weight) & 65 & 70 & 70 \\
\hline DPG (\% by weight) & 32,5 & 27,5 & 26,5 \\
\hline DBA (\% by weight) & 2,5 & 2,5 & 3,5 \\
\hline Reaction temperature ( $\left.{ }^{\circ} \mathrm{C}\right)$ & 200 & 200 & 200 \\
\hline Reaction time (min) & 60 & 60 & 60 \\
\hline Hydroxyl No. (mg KOH/g) & 296 & 248 & 257 \\
\hline Amine No. $(\mathrm{mg} \mathrm{KOH} / \mathrm{g})$ & 23 & 16 & 18 \\
\hline Viscosity $\left(25^{\circ} \mathrm{C}\right)(\mathrm{mPas})$ & 22,370 & 87,500 & 66,000 \\
\hline
\end{tabular}

The compression strength of the foam is decreased by only $12 \%$ when adding up to $20 \%$ by weight of the recycling polyol while compression set shows no change. When adding larger amounts of the recycling polyols the foams tend to get a higher proportion of closed cells and to shrink. The reason for this phenomenon has not been elucidated but maybe attributed to the cell stabilizers originally present in the foam formulations. The demoulding times turn out to be under lab conditions somewhat shorter than the formulation based on primary polyols.

When using recycling polyols of this type the hardness of the free rise foams is efficiently controlled by the isocyanate index (Behrendt \& Pohl 1998). It has to be pointed out that the higher the amount of recycling polyol added the lower the isocyanate index should be formulated so as to produce maximum flexibility of the foams. When employing $30 \%$ by weight of the recycling polyol the index may kept as low as 50 in the total stoichiometric balance (including water). Thus, the formulation is produced more economically by reducing the amount of polymeric MDI necessary for foaming.

\subsection{SHOE SOLE PRODUCTION WASTES}

Wastes of the shoes sole production are of polyether or polyester type (Stoychev et al. 2010). Both types were subjected to solvolysis and introduced into the original systems again. The solvolysis did not need a change in batch technology but in the continuous mode. The following table 12 shows some results obtained with both polyether and polyester shoe soles at various degrees of solids content.

The originally employed polyester diols used in shoe sole production are at room temperature semi solid or solid materials. The viscosity is measured and presented at $25^{\circ} \mathrm{C}$ while the temperature at working conditions is in the range of $55^{\circ} \mathrm{C}$. Hence, the viscosities of the recycling polyols are at $55^{\circ} \mathrm{C}$ in the range of the original polyesters. Depending on the technology of the customer, the amount of solids in the mixture maybe as high as $80 \%$ by weight to give a material being semi solid (paste-like) at room temperature and having a viscosity of about 2500 $\mathrm{mPas}$ at $55^{\circ} \mathrm{C}$.

Polyether based shoe sole wastes were solvolised in the same way. As in any other case, also with this material the conditions had to be developed and adjusted to the material. Some of the results with higher proportions of solids are depicted in table 13. 
Tab. 13: Recycling polyols obtained from polyether shoe soles

\begin{tabular}{|c|c|c|c|c|c|}
\hline Item/No. & 056 & 057 & 059 & 060 & 061 \\
\hline PUR (\% by weight) & 60 & 55 & 70 & 63 & 65 \\
\hline DPG (\% by weight) & 35,5 & 40,5 & 26,5 & 33,0 & 30,5 \\
\hline DBA (\% by weight) & 4,5 & 4,5 & 3,5 & 4,0 & 4,5 \\
\hline Reaction temperature $\left({ }^{\circ} \mathrm{C}\right)$ & 200 & 200 & 200 & 200 & 200 \\
\hline Reaction time (min) & 30 & 30 & 30 & 30 & 30 \\
\hline Hydroxyl No. (mg KOH/g) & 380 & 383 & 257 & 279 & 254 \\
\hline Amine No. $(\mathrm{mg} \mathrm{KOH} / \mathrm{g})$ & 15 & 18 & 27 & 31 & 18 \\
\hline Viscosity $\left(25^{\circ} \mathrm{C}\right)(\mathrm{mPas})$ & 2,720 & 1,780 & 11,930 & 2,430 & 8,800 \\
\hline
\end{tabular}

Due to the general lower viscosities of the polyether polyols there are two choices: either the viscosity can be kept low, e. g. at about $3000 \mathrm{mPas}\left(25^{\circ} \mathrm{C}\right)$ having a solids content of about $63 \%$ by weight, or the amount of solids is high, e. g. $70 \%$ by weight, when the viscosity is apt to be processed by the technology employed by the applicant and easily reaches $15,000 \mathrm{mPas}$ $\left(25^{\circ} \mathrm{C}\right)$. Even higher percentages of solids are possible. It was shown that even at $85 \%$ by weight of solids a semi solid recycling polyol can be produced showing a viscosity at $25^{\circ} \mathrm{C}$ of about 80,000 mPas. In any case, the applicant of such recycling polyols has to carefully determine the parameters aimed at which should be completely in concordance with the technology employed.

The recycling polyols were introduced into typical shoe sole systems at rates up to $40 \%$ as calculated on the basis of the premix component. If the premixes are changed by the applicant or supplier, especially by eliminating some of the chain extenders ethylene glycol and/or butane-1,4-diol, the glycol of the solvolysis mixture may take over part of their function in establishing a certain phase segregation in the polyurethane and further adding to the rigidity of the material (Stoychev et al. 2011). Such experiments are under way.

\section{CONCLUSIONS}

The combined glycolsysis/aminolysis is the basis of a new polyurethane recycling process well suited to produce recycling polyols of good quali- ty from various polyurethane sources. It has been shown by a multitude of lab and semi-technical scale experiments that for each type of polyurethane a special formulation has to be developed, that a formulation fitting for one product cannot be transferred without problems to another product even of the same type but the solvolysis mixture has always to be carefully reformulated and adjusted to the product under consideration. Further, it has been shown that the recycling polyols maybe produced at various scales with identical parameters as shown with the hydroxyl numbers and viscosity. The reaction conditions further influence the quality of the product with respect to homogeneity and colour. The colour of the recycling polyols - in general yellow to dark amber - does not affect the foam properties and is not a result of oxidation during the pro-cess but more that of a side reaction of minor contaminants and does not deepen on longer addition or reaction times. Fillers or pigments remain in the recycling polyols, thus leading to products with the colour of the original polyurethane or - in case of mixtures of several colours - of a mixed colour. In some cases a solids content of the polyurethanes up to $20 \%$ by weight was found and stabilized in the recycling polyol either by the viscosity (where the appearance of tixotropy has to be avoided) or at lower viscosities (e. g. 2000 mPas) with agitation of the polyol in the storage container. The polymers grafted to polyether alcohols as in the grafted polyols may either be formed into a needle-like material and filtered off or finely dis- persed and remain in the recycling polyol to be introduced into the new polyurethane again.

The solids content of the recycling polyol is in case of elastic types usually in the range of $60 \%$ by weight to meet viscosity requirements. It maybe increased to up to $85 \%$ by weight but in these cases the viscosity at $25^{\circ} \mathrm{C}$ exceeds processing conditions so that processing is possible only at elevated temperatures. The latter holds especially in the case of polyester based shoe soles. With rigid foams the amount of solids is limited to about $50 \%$ by weight to meet acceptable viscosities.

The recycling polyols maybe used as single components in the production of composites, coatings, or sealants, i. e. a new type of material. Attempts to introduce them into formulations similar to the original products have shown that depending on the type of polyurethane produced between 15 and $40 \%$ by weight of the premix component maybe substituted by the recycling polyol without detrimental effects on the final product properties.

Thus, the solvolysis by combined aminolysis and glycolysis represents not only a much faster and simpler way to produce recycling polyols from a variety of polyurethane products but also gives recycling polyol with qualities allowing them to be introduced into formulations of the original products as well as in such for completely different products. The process and the apparatus to perform the process are available up to volumes of 6 met- 
ric tonnes thus allowing for an annual production of up to 4,500 metric tonnes in the three shift system. The process is economical in that way as the production costs at an annual production exceeding 250 metric tonnes are far below the primary raw materials and usually in the range of $€ 0.50$ (or equivalent \$0.62).

Remark: Article based on a presentation held at STI Conference Nyeri (Kenia), 04.-07.11.2014

\section{REFERENCES}

Behrendt G, Naber BW (2009) The chemical recycling of polyurethanes. J Univ Chem Technol Metallurgy 44(1):3-23

Behrendt G, Pohl M (1998) Verfahren zur Herstellung von Polyurethanen. Patent Application DE 19817 539.6, PCT/EP1999/002604, 16 Apr 1998

Behrendt G, Pohl M (1999) Verfahren zur Herstellung von Polyolen sowie Polyole. Patent DE 19917 932, 21 Oct 1999

Behrendt G, Pohl M (2004a) Method for producing polyols and polyols. Patent US 6,683,119, 27 Jan 2004

Behrendt G, Pohl M (2004b) Verfahren zur Herstellung von Polyolen sowie Polyole. Patent EP 1086 169, 11 Feb 2004

Belke M, Pniok I, Evtimova R, Langenstraßen R, Behrendt G (2003) Closed Loop of Polyurethane Flexible Slabstock Foam Wastes by a Chemical Process. In: Polyurethane Foam Association Conference, Oct 2003, Montreal, Canada

Evtimova R, Madjarova R, Georgieva D, Hunger $\mathrm{H}$, Behrendt G (2004) Polymer Wood Composites Based on Recycling Products from Condensation Polymers. In: Conference on Ma-nufacturing and Management, 2004, Ohrid

Langenstraßen R, Behrendt G, Diener R, Gebert B (2001) Verfahren und Vorrichtung zur kontinuierlichen Herstellung von Polyurethan-Recyclingpolyolen. Patent Application DE 10313 150.7, 11 Jan 2001

Schmidt K, Koch H, Pohl M, Huth H, Ivanyi S, Stürmer O, Behrendt G (2001) Entwicklung von PolyurethanBeschichtungssystemen auf der Basis von RecyclatPolyolen aus Polyurethan-Weichschaumstoffen. Wiss Beitr TFH Wildau 6:28-37

Stoychev V, Evtimova R, Herzog M (2011) Recycling von Polyurethanen mittels Aminolyse. PU-Magazin 11(4):193-196

Stoychev V, Herzog M, Behrendt G (2010) Chemical Recycling of Polyurethane Integral Foams and Shoe Soles. In: Advanced Topics in Manufacturing Engineering and Management, 25-26 Nov 2010, Košice, Częstochowa, pp 24-27

\section{AUTHORS}

Dipl.-Chem. Silke Beckmann Technische Hochschule Wildau silke.beckmann@th-wildau.de

\section{Prof. Dr. rer. nat. Michael Herzog}

Technische Hochschule Wildau

michael.herzog@th-wildau.dee 